\title{
THE EFFECT OF POLICIES OF THE RBI ON ISSUING NEW BANK LICENCES FROM POST NATIONALISATION OF BANKS IN INDIA
}

\author{
Dr.K.Thirumamagal \\ Principal in Charge \& Head, Department of Commerce (Accounting \& Finance) \\ S.S.K.V College of Arts \& Science for Women, Kanchipuram
}

Article DOI: https://doi.org/10.36713/epra7084

DOI No: 10.36713/epra7084

\begin{abstract}
In this modern scenario, Finance has become the foremost basic necessity in order to acquire the other necessities of life. The prominent financial sector are regulated by different regulatory authorities with a prime motto of protecting the interest of the customers and to uplift the weaker sections of the society. Since this strife-torn world is full of conflicts, corruption which has affected the economic stability of the state, the regulatory authorities should seriously analyze the effect of licenses going to be provided in 2014 and also it has to take in to account that the empires down the history have been known to get built only to be lost subsequently. The objective of this study is to impart the essential standards the banks of India should possess and also the challenges going to be faced by our economy due to the reckless decision of the regulatory authority. The need of this study is to safeguard the customers of us from the unscrupulous businessmen. This paper study the role of central bank and to analyze the result of providing license to the private sector, particularly the corporate houses, which is not practiced anywhere in the world.

KEY WORDS: Corporates, Banks, Finance, Non Performing Asset, innovative, technology, Licenses, RBI
\end{abstract}

\section{INTRODUCTION}

Finance is the heartthrob of our country. This is a strife- torn world with full of corruption, conflicts, complicity and unhealthy competition affecting the stability of economic state. In order to have a stabilized economy the country should have a prominent financial sector and it should be regulated by the authorities whose prime motto should focus on protecting the interest of customers. The financial sector of India comprises of Commercial banks, insurance companies, non banking financial institutions, regional rural banks, housing finance companies ,capital markets and mutual funds, pension funds and all these sector are regulated by different authorities. Commercial banks are regulated by the Reserve Bank of India Act 1934, Insurance Companies by Life Insurance Corporation of India Act 1952, General Insurance 1972 and Insurance Regulatory Development Authority of India, Regional Rural Bank by NABARD, Housing Finance
Companies by National Housing Bank and also by Department of Company Affairs, Capital markets and Mutual Funds by SEBI. Each regulators frame their own set of rules and regulations and redress the grievance of their customer through their grievance redressal forum. Eventhough the financial sector are regulated by different authorities which is under the purview of Government of India, the money laundering by some sector shook the country for a while. Government and regulators in countries like India have come up with policy measures to nudge financial sectors to increase access and usage of financial products by the poor.

\section{REVIEW OF LITERATURE}

Pavan Mishra\& Payal Sharma;2011 provide the role of the central bank on new banks explores the option of allowing large industrial houses into the space. He pointed out that in support of roping in these 
business houses to grow the banking space, the Reserve Bank of India (RBI) says there may not be too many other entities that are able to muster the capital, especially if the threshold is high. He also added that the central bank also lauds the entrepreneurial and managerial talent available in industry and cites an IMF study, which concludes that industrial companies could act as a source of contingent capital for banks.

Santosh Kumar Das and Imed Drine; 2011 finds that the Indian financial sector has undergone a significant structural transformation since the initiation of financial liberalization during 1990's. It brought significant changes in the financial sector in general and banking in particular. While there have been significant changes in the financial structure, India remains a bank dominated financial system. One of the major objectives of financial liberalization was to make the financial institutions more efficient and competent. Against this backdrop, the paper intends to analyze the cost efficiency of the Indian banking sector. Ihe study finds, the public sector banks are the most efficient banks followed by the domestic private sector and foreign banks. The finding of the study is quite contrary to the international evidence. There could be several potential expiations to this unconventional finding. First, the natural monopoly argument--the public sector banks got the advantage of the first mover and also the economies of scale. Second, the time period of the study is the period of consolidation for the foreign banks and the new private banks. He concluded that it is because, several banking specific reforms as a part of financial sector reform went on till late 1990's.

Stephen Timewell; 2012 provide a preliminary comparative investigation of the growth of entrepreneurs through the credit service of public and private sector banks in India. The result of the statistical analysis indicates that private sector banks are providing more satisfactory service as compared to public sector banks. Empirical evidences indicates that customers perception about Efficiency, Security and Responsiveness, Cost Effectiveness, Problem Handling and Compensation and Contact service is low in both public and privates sector banks.

Das, Abhiman \& S. Ghosh. (2006). The researcher investigated the performance of Indian commercial banks during the post reform period. He suggested that the medium sized public sector banks performed reasonably well and those banks are more likely to operate at higher level of technical efficiency

\section{NEED FOR THE STUDY}

The need of the study is to analyse the new licences issued to private sector from 1993 to till date and to suggest some parameters for the new private entry with adequate focus on economic development of our country inspite of the parameters fixed by the Reserve Bank of India, which in turn will definitely create a market driven banking sector. This paper studies the role of banks in the economic development of the country during pre and post nationalization and the effect of new bank licenses.

\section{OBJECTIVES OF THE STUDY}

The objectives of this study are

- To analyze the role of Indian banks before and after nationalization.

- To assess the Non Performing Assets of Corporate who have applied for the bank license

- To provide some suggestions with regard to the essential standards the RBI should apply to initiate the process of providing licenses to new banks and also the role that has to be played by the new banks in financial inclusion.

\section{METHODOLOGY OF THE STUDY}

The study is purely descriptive in nature and all the data used for conducting research were taken from secondary sources such as published reports of RBI,NABARD, Census Surveys, Books, newspapers, journals, websites etc.,

\section{HISTORY OF THE BANKING SECTOR}

The origin of banks can be traced back to the last decades of $18^{\text {th }}$ century. The first banks established by the country were Bank of Hindustan during the year 1770 and the General Bank of India during 1786. Calcutta became the banking centre mainly due to the trade of British Empire. Union bank of Calcutta was established in 1829, which failed and became insolvent due to the frauds committed by the accountants of the concern bank. The largest and oldest bank still in existence is State Bank of India originated from Bank of Calcutta in June 1806. The banks which were established during the invasion of the Britishers and still in progress were Allahabad Bank and Punjab National Bank. More than 90 banks failed between 1913 and 1918. During post-independence era our country seems to be behind the times in respect of banking and also like some old fashioned sailing ship, divided by solid wooden bulkheads in to separate and cumbersome compartments when compared globally with other countries. To move in to next orbit, it is 
vital to understand the environment, the inefficiencies, the pitfalls that limits growth and build on synergies and innovation for capitulating it in to the future. . In order to stabilize the economy, the Government of India has taken a major step after independence.

- Establishment of Reserve Bank of India under the terms of Reserve Bank of India(transfer to public ownership) Act 1948

- Banking Regulation Act 1949 was enacted which empowered Reserve Bank of India to regulate, control and inspect the banks in India.

- No new banks or branch should be established without licence from Reserve Bank of India and no two banks could have common directors.

\section{NATIONALISATION IN THE 1960'S}

Although there has been improvement in the banking sector, the achievement is not significant since it is not under the purview of the Government. Most of the banks were owned by the private people. The money lenders and indigenous bankers were still dominant source of rural finance despite wide presence of banks in rural areas. The financial inclusion has become the centerpiece of national effort for poverty reduction and economic stability. It became a globalised issue. In order to extend the banking services to the unreached, the nationalization of banks took its root to connect the unbanked segments of our population to financial services. Despite the provisions of the Reserve Bank of India Act except State Bank of India, all other banks were owned by the private persons. Indira Gandhi, the then prime minister had taken a sudden measure of nationalizing 14 banks by passing an ordinance ( Banking Companies Acquisition and Transfer of undertaking) Ordinance 1969 in order to facilitate the development of Indian Economy. It was a masterstroke of political sagacity. Another six banks were nationalized during 1980 in order to have more control of credit delivery. The government of India had a control of $91 \%$ of banking business due to this nationalization. Only one merger took place in the year 1993, New Bank of India with Punjab National Bank, there by reducing the nationalized banks from 20 to 19. Nationalisation was done in order to overcome economic troubles after first world war and to support the economic plan with loans and also to restructure the national benchmark from bank crashes and also one of the key reasons for the nationalization of banks was that many were controlled by large business groups that used public deposits to finance their own businesses.

\section{LIBERALISATION IN THE 1990'S}

Due to the devaluation of Indian rupee against US dollar, our economy came down in July 1991 in order to stabilize our country, new guidelines were issued in 1993 to establish private banking sector with deregulated bank interest by the central bank. Since the first phase of providing platform to private sector was a success, the central government further ahead towards future developments in the financial markets encouraged private entry of banks. They hoped the new private banks would be such driver for India's financial system and also it should be noted that no banks have been allowed to set up in private sector after the nationalization of 14 banks in 1969 . there was a drastic change during 1993. In order to recognize the role of public sector banks, there was increasing recognition of the need to introduce greater competition which can lead to high productivity and efficiency of the banking system. This lead to the entry of private banks. New Generation tech-savvy banks such as HDFC, ICICI,UTI,Global Trust Bank were established during 1990. The adoption of new technology has changed the entire scenario of private banking sector and made them to compete with the international banks in terms of customer service. 
Table 1.1

Banks licensed under the 1993 guidelines

\begin{tabular}{|c|c|c|c|c|}
\hline Sl. No. & Name of the bank & Date of licence & $\begin{array}{l}\text { Name of the } \\
\text { promoters }\end{array}$ & $\begin{array}{l}\text { Present position } \\
\text { of the bank }\end{array}$ \\
\hline 1 & Axis Bank LTD. & $28-02-1994$ & $\begin{array}{c}\text { Financial } \\
\text { institutions : } \\
\text { SUUTI and LIC }\end{array}$ & Still functioning \\
\hline 2 & IndusInd Bank Ltd. & 2-04-1994 & $\begin{array}{c}\text { Individuals : } \\
\text { Hindujas, through } \\
\text { a number of } \\
\text { companies } \\
\text { representing } \\
\text { Sindhi community }\end{array}$ & $\begin{array}{l}\text { Still functioning } \\
\text { with muted growth }\end{array}$ \\
\hline 3 & ICICI Bank Ltd. & $17-05-1994$ & $\begin{array}{c}\text { Financial } \\
\text { institutions : } \\
\text { ICICI }\end{array}$ & Still functioning \\
\hline 4 & $\begin{array}{l}\text { Global Trust Bank } \\
\text { Ltd. }\end{array}$ & 2-09-1994 & $\begin{array}{l}\text { Individuals: } \\
\text { group of } \\
\text { professionals led } \\
\text { by Dr. Jayant } \\
\text { Madhab and } \\
\text { Ramesh Gelli }\end{array}$ & $\begin{array}{l}\text { Compulsorily } \\
\text { merged with } \\
\text { Oriental Bank of } \\
\text { Commerce due to } \\
\text { erosion of } \\
\text { networth }\end{array}$ \\
\hline 5 & HDFC Bank Ltd. & 5-01-1995 & $\begin{array}{c}\text { Financial } \\
\text { institutions : } \\
\text { HDFC group }\end{array}$ & Still functioning \\
\hline 6 & Bank of Punjab Ltd. & 5-04-1995 & $\begin{array}{c}\text { Individuals : } \\
\text { principal } \\
\text { shareholders of } \\
\text { Punjab \& Sind } \\
\text { Bank prior to } \\
\text { nationalisation }\end{array}$ & $\begin{array}{c}\text { Voluntary } \\
\text { amalgamation with } \\
\text { Centurian Bank on } \\
\text { 1-10-2005 }\end{array}$ \\
\hline 7 & Times Bank Ltd. & 26-04-1995 & $\begin{array}{l}\text { Times of India } \\
\text { Group }\end{array}$ & $\begin{array}{c}\text { Voluntary } \\
\text { amalgamation with } \\
\text { HDFC Bank Ltd. on } \\
\text { 26-2-2000 }\end{array}$ \\
\hline 8 & DCB Ltd. & 31-05-1995 & $\begin{array}{c}\text { Conversion of a Co- } \\
\text { operative bank - } \\
\text { promoter Agha } \\
\text { Khan }\end{array}$ & Still functioning \\
\hline 9 & $\begin{array}{c}\text { Centurion Bank } \\
\text { Ltd. }\end{array}$ & 13-06-1995 & $\begin{array}{c}\text { Individuals : } \\
\text { Demerger of an } \\
\text { NBFC, promoter } \\
\text { Shri Ahuja, ex-Citi } \\
\text { Bank man and } \\
\text { others }\end{array}$ & $\begin{array}{c}\text { Voluntary } \\
\text { amalgamation with } \\
\text { HDFC Bank Ltd. on } \\
\text { 23-5-2008 }\end{array}$ \\
\hline 10 & IDBI Bank Ltd. & 28-09-1995 & $\begin{array}{c}\text { Financial } \\
\text { institutions : } \\
\text { IDBI }\end{array}$ & Still functioning \\
\hline
\end{tabular}


The Licenses issued to the Banks in the year 1993 were revised in January 2001 and as a result two more banks were set up in the private sector. Since 2001 , there was a phase of consolidation in the Private Sector Banking scenario. In the same year 15 amalgamation of banks took place. Out of which 9 is voluntary amalgamation and 6 compulsory amalgamation with stronger banks which is presented in Table 1.1.. On May $11^{\text {th }} 2005$, a circular for the process of amalgamation was released by Reserve Bank of India. It was felt that the immediate need of the hour is to strengthen the banking system for financial inclusion than setting up of new banks in Private Sector.

Table 1.2

Banks licensed under 2001 guidelines

\begin{tabular}{|c|c|c|c|c|}
\hline SI.No & $\begin{array}{c}\text { Name of the } \\
\text { Bank }\end{array}$ & $\begin{array}{c}\text { Date of the } \\
\text { License }\end{array}$ & $\begin{array}{c}\text { Name of the } \\
\text { Promoters }\end{array}$ & $\begin{array}{c}\text { Present Position } \\
\text { of the Bank }\end{array}$ \\
\hline 1 & $\begin{array}{c}\text { Kotak Mahindra } \\
\text { Bank }\end{array}$ & $6-02-2003$ & NBFC & Still functioning \\
\hline 2. & Yes Bank Ltd & $24-05-2004$ & $\begin{array}{c}\text { Individuals along } \\
\text { with Rabo Bank }\end{array}$ & Still Functioning \\
\hline
\end{tabular}

Source: www.rbi.org

\section{RECOMMENDATIONS OF VARIOUS COMMITTEES}

Committees set up by Government of India has given various recommendations for setting up of new banks in private sector. Some of the recommendations were as follows:

1. In December 2004, The High Level Investment Commission was constituted by the Government of India and in February 2006 it has presented its report stating that ownership can be permitted to Indian Corporates in Indian banks up to $15 \%$ and it has also recommendated to increase the limit of holdings by any one foreign bank up to $15 \%$ in private banks.

2. In March 2006, The High Level Committee on Fuller Capital Account Convertibility was constituted by the Reserve Bank of India under the Chairmanship of Shri.S.S.Tarapore. The committee has presented its report on July 2006 and gave reccomendations on the encouragement of NBFCs to convert themselves in to Banks and also they recommended that the foreign banks can be allowed to enhance their presence in Indian Banking System.

3. In August 2007, a High Level Committee on Financial sector reforms was constituted by the Government of India under the Chairmanship of Dr.Raghuram G. Rajan. It has submitted its report on September 2008 and recommended allowing more entry to private well governed deposit taking small finance banks with stipulation of higher capital adequacy norms, a strict prohibition on related party transactions, and lower allowable concentration norms.
The Reserve Bank of India has released a Discussion paper on the entry of new banks on its website on August $11^{\text {th }} 2010$ based on international practice of granting licenses to new banks. The RBI asked suggestions and comments of banks on the discussion paper. The paper was mainly on permitting industrial or business houses to set up banks. The guidelines for granting licences to new banks was constantly given by the Reserve Bank of India based on the scenario of the economic status of the Country.

On June 12 2020, Internal Working Group was constituted by the Reserve Bank India to review the Ownership guidelines and corporate structure for Indian Private sector banks. The IWG has submitted its report and gave 12 recommendations on the eligibility criteria for entities to apply for banking licences, examination of preferred corporate structure for functioning of banks and norms to be followed and review of old norms for long term shareholding in banks by the promoters and other shareholders.

\section{ENTRY OF NEW BANKS AND AN OVERVIEW OF THE FINANCIAL CRISIS AND CORPORATE SCANDALS}

After Harshad Mehta's case, there was a sudden growth of scam cases. In 1993, Investors lost roughly INR 5,000 crores when transnational companies allotted the equity shares to their respective controlling groups at steep discount to their market price in order to consolidate their ownership. Many companies vanished without any profile during 1993-94. The RBI, regulatory authority of India has to protect the depositors. After approaching various banks for merger, it finally zeroed in on Oriental Bank of Commerce as its NPA level had come down drastically. The major drawback of this scandals are a negligible portion of share capital are owned by the promoters 
families and rule the companies as if they are their personal fiefdoms. Why the industries entered the scenario with a lot of fanfare and hype and left out without any trace of them is because of the unethical practices and illegal tactics of our genius Indian corporates. These history should be considered by the RBI before providing licence to the corporates who have applied for it. The RBI received as many as 26 applications for bank licences on the close of july 1 after initimation for licensing was issued by RBI on February $22^{\text {nd }} 2013$. The RBI also announced that initially the license will be scrutinized by itself and it will be scrutinized by a committee formed under the chairmanship of former RBI Governor Bimal Jalan with three members former Deputy Governor Usha Thorat, Former SEBI Chairman C.B,Bhave and Nachiket Mor, Former ICICI Bank Official. In the past 20 years RBI has issued licences to 12 banks in the private sectors in two phases. Ten banks were licenced in January 1993 and two in second phase after scrutinizing 133 applications. Only 12 got the green light.
There was no major difference in establishment of banking sector in rural areas between 2001 to 2009 . In order to get banks to reach the unreached Reserve Bank of India took the initiative of licensing new banks during 2010 itself and thereby The Banking Laws (Amendment) Bill 2012 has been passed in the winter session of the parliament of India on $18^{\text {th }}$ December 2012 by the lower house of the parliament and on $20^{\text {th }}$ December 2012 by the upper house of the Indian Parliament in order to strengthen the regulatory powers of the RBI and to further develop the banking Sector in India. The bill aims to address the the issue of capital raising capacity of banks in India by enabling nationalized banks to raise capital by issue of preference shares or rights issue or issue of bonus shares. It would also enable them to increase or decrease the authorized capital with approval from the Government and RBI without being limited by the ceiling of a maximum of Rs. 3000 crore. The Bill would also pave the way for new bank licenses by RBI resulting in opening of new banks and branches.

\section{OVERVIEW OF THE BILL THROUGH FLOWCHART REPRESENTATION}

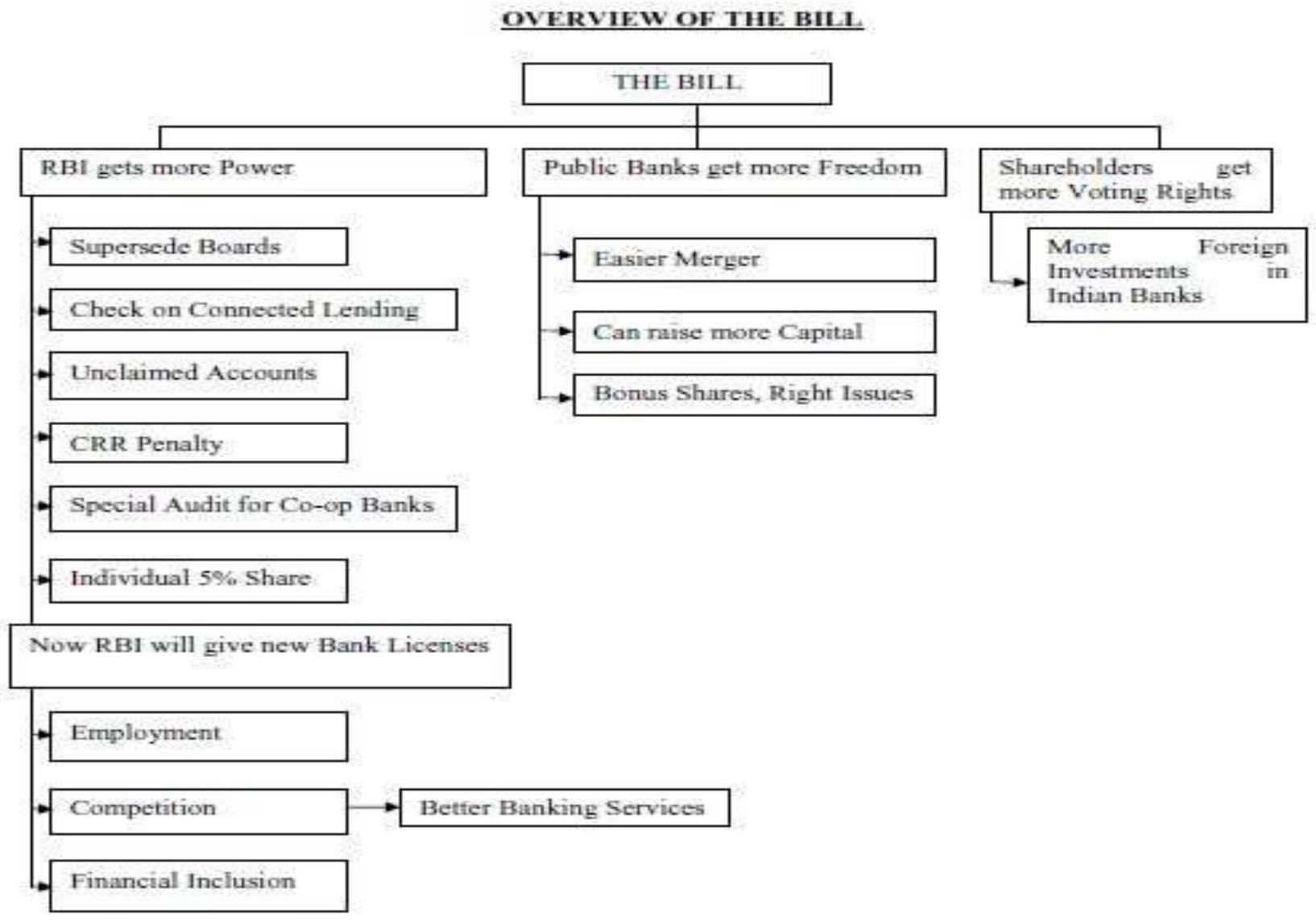


Worries begin to be voiced about financial stability after the entry of corporates in getting bank licences whether would it be appropriate to consider them as good vehicles for development programme or should they be encouraged to take interest in multidimensional approach to poverty alleviation and empowerment of the poor.

The present guidelines state that

- New banks can be started by residents or by NBFCs converting themselves, with at least Rs. 500 cr. of capital.

- New banks will be held by a financial holding company that holds all the financial assets of the promoter group. So if an entity that is currently a broker or an NBFC applies, the holding company will have to hold the promoter shares in that entity, and the RBI will regulate the holding company. Stock Brokers, Insurance companies etc. can apply as well, under this rule.

- The holding company must own at least $40 \%$ of the bank for five years. In fact, after three years it has to hold exactly $40 \%$. Within ten years, this needs to come down to $20 \%$, and within 12 years, $15 \%$.

- The capital adequacy Ratio (CAR) of the new banks should be at least $13 \%$.

- Banks need to list (not the holding company, but the bank) within 3 years.

- Foreign shareholding cannot exceed $49 \%$ in the first five years, and no single foreign shareholder can own more than 5\%.

- There are detailed regulations for holding company exposures, consolidation, valuation etc.

- No single entity can hold more than $10 \%$ of voting capital, with RBI approval required for any increase that takes it to more than $5 \%$.

- Banks need to have core banking upfront, a customer grievance procedure rightaway, and have $25 \%$ of branches in rural "unbanked" areas.

\section{FINDINGS AND SUGGESTIONS}

There is no practice of giving license to the corporate houses anywhere in the world. What is the reason behind some corporates who have not enrolled in this licensing process(kotak mahindra, sundaram finance). It's the time to reflect on what the new banks should achieve including expectations on financial inclusion. While inclusion articulated as the physical presence of banks in unbanked locations is important, it glosses over exclusion in urban areas. Already some parameters are fixed by the RBI for the new banks. The following parameters can also be considered for the new entry

- It has been fixed that it should have an authorized capital of 500 crores. It can be more than the prescribed limit.

- The banks should adopt at least FIVE villages where the people are unbanked.

- The banks should show progress in the adopted villages within the period of 2 years. If they do so then only they will be allowed to open more no of branches in urban areas too.

- If they are accused of indulging in money laundering within the period of these two years, they have to be not only penalized but also their license has to be taken back by the RBI.

- The new banks should become the masters of the universe. Confidence, sophistic ideology and sheer ignorance combined to drive the boom and bust.

\section{CONCLUSION}

The banking sector needs to fundamentally strengthen the institutional skill levels, strengthening human capital will be the single biggest challenge. Banks could reach the next level of their growth in Indian banking sector by continuing to innovate and develop differentiated business to profitably serve all segments of the society. We need a good value system to march ahead in this globalised world and we should be model for others in the world.

\section{REFERENCES}

1. Bhattacharya, A., Lovell, C.A.K., and Sahay, P. (1997). The impact of liberalization on the productive efficiency of Indian commercial banks. European Journal of Operational Research, 98, 332-345.

2. Das, Abhiman \& S. Ghosh. (2006). Financial Deregulation and Efficiency: An Empirical Analysis of Indian Banks During the Post Reform Period. Review of Financial Economics, 15(3), 193-221.

3. Goyal, K. A. and Joshi, V. "Mergers in Banking Industry of India: Some Emerging Issues”.Asian Journal of Business and Management Sciences, 1(2): 157-165, 2011a.

4. Mohan, Rakesh. (2005). Reforms, Productivity and Efficiency in Banking: The Indian Experience. Pakistan Development Review, 44(4), 505-538.

5. Prasad, A and S. Ghosh. (2005). Competition in Indian Banking. IMF Working Paper WP/05/141.

6. Ram Mohan, T T. (2007). Banking Reforms in India: Charting a Unique Course. Economic and Political Weekly March 31, 1109-1120. 
7. Ray, S. C \& A. Das. (2009). Distribution of Cost and Profit Efficiency: Evidence from the Indian Banking. European Journal of Operational Research.

8. Reserve Bank of India. (2002). Report on currency and finance 2001-02, Mumbai.

9. Reserve Bank of India. Statistical tables relating to banks in India (various years),

10. Reserve Bank of India reports on licencing of banks from 1993 to 2020

11. Standing Committee on Finance (2013-14) fifteeth Lok Sabha, Ministry of Finance(Department of Financial services) Policy of New Licences in the Banking Sector.

12. Santosh Kumar Das and Imed Drine; 2011 "Financial Liberalization and Banking Sector Efficiency in India:A Fourier Flexible functional form and Stochastic Frontier Approach", International Business and Management, Vol.2, No.1, February 28, 2011

13. Sen, Kunal \& R. Vaidya. (1997). The Process of Financial Liberalization in India. Delhi, India: Oxford University Press

14. Shrieves, $R$. E. "The relationship between risk and capital in commercial banks". Journal of Banking \& Finance, 16(2): 439-457, 1992.

15. "What RBI says about new banks." Financial Express 12 Aug. 2010. General One File. Web. 17 Jan. 2013 